\title{
Profile of rural properties with dairy production and its reflexes in the future: health problem and water contamination
}

Crop protections have a great dispersion capacity, consequently human exposure to these chemicals can cause several diseases. Thus, this study aimed to present data on rural properties with dairy production in the Taquari Valley in relation to the use of crop protections associated with health problems and water contamination. All participants were interviewed, determined the Quality of Life (QoL) by Whoqol-bref instrument and collected water for physical-chemical analysis. Of the 86 rural producers interviewed, 79 make controlled application, 11 of which do not control the application in the vicinity of wells, streams and improvements. Only three producers use crop protection products without control close to water courses and four do not use crop protection products on the property. The overall average QoL of rural producers was considered adequate for all domains, being above average. Regarding the physical-chemical parameters, the water destined for human consumption presented compliance with the legislation. However, for total and thermotolerant coliforms, water was considered unfit for human consumption, not complying with the legislation. Raising awareness of a better quality of life for rural producers, minimizes risks to human and animal health and the environment, ensuring quality of life for future generations.

Keywords: Crop protections; Dairy production; Rural worker; Water contamination.

\section{Perfil de propriedades rurais com produção leiteira e seus reflexos no futuro: problema de saúde e contaminação da água}

\begin{abstract}
Os agrotóxicos possuem grande capacidade de dispersão, consequentemente a exposição do ser humano a estes produtos químicos podem causar diversas doenças. Nesse contexto, este estudo teve como objetivo apresentar dados de propriedades rurais com produção leiteira do Vale do Taquari em relação ao uso de agrotóxicos associando a problemas de saúde e contaminação das águas. Foram realizadas visitas in loco às propriedades selecionadas sendo aplicado o instrumento de avaliação Whoqol-bref para avaliar a Qualidade de Vida (QV). Assim, dos 86 produtores rurais entrevistados, 79 fazem aplicação controlada, sendo que 11 destes, não controlam a aplicação nas proximidades de poços, córregos e benfeitorias. Apenas três produtores utilizam defensivos agrícolas sem controle próximo aos cursos de água e quatro não fazem uso de defensivos agrícolas na propriedade. Os defensivos agrícolas mais utilizados são Roundup, Glifosato Primóleo e Calisto, respectivamente. A média geral de QV dos produtores rurais foi considerada adequada para todos os domínios, encontrando-se acima da média. Em relação aos parâmetros físico-químicos as águas destinadas ao consumo humano apresentaram conformidade com a legislação. No entanto para coliformes totais e termotolerantes a água foi considerada imprópria para consumo humano, não estando em conformidade com a legislação. A conscientização para melhor qualidade de vida do produtor rural, bem como a garantia de preservação ambiental devido ao uso de agrotóxicos minimiza os riscos à saúde humana e animal, e ao meio ambiente, garantindo qualidade de vida às futuras gerações.
\end{abstract}

Palavras-chave: Agrotóxicos; Produção leiteira; Trabalhador rural; Contaminação da água.

Topic: Desenvolvimento, Sustentabilidade e Meio Ambiente

Reviewed anonymously in the process of blind peer.
Received: 04/02/2021

Approved: 25/02/2021
Fernanda Majolo (iD)

Pontifícia Universidade Católica do Rio Grande do Sul, Brasil

http://lattes.cnpq.br/3363064142425982

http://orcid.org/0000-0002-7955-078X

fernanda.majolo@acad.pucrs.br

\section{Claudete Rempel (ib)}

Universidade do Vale do Taquari, Brasil

http://lattes.cnpq.br/8340497822227462

http://orcid.org/0000-0001-8573-0237

crempel@univates.br

Patrícia Caye Bergmann

Universidade do Vale do Taquari, Brasil

http://lattes.cnpq.br/8497886339173527

http://orcid.org/0000-0003-0081-9158

patricia.bergmann@universo.univates.br
Gustavo Rodrigo da Silva (iD)

Universidade de Mogi das Cruzes, Brasil

http://lattes.cnpq.br/4580848075797987

http://orcid.org/0000-0003-2669-4365

gustavo.silva1@universo.univates.br
Referencing this:

MAJOLO, F.; REMPEL, C.; BERGMANN, P. C.; SILVA, G. R.. Profile of rural properties with dairy production and its reflexes in the future: health problem and water contamination. Revista Ibero Americana de Ciências Ambientais, v.12, n.2, p.506-516, 2021. DOI: http://doi.org/10.6008/CBPC2179-6858.2021.002.0043 


\section{INTRODUCTION}

Once the population starts to live longer it is necessary the production of more and more food and a larger offer of products and services. In one way or another, this falls a great deal on the populations living in rural areas. This population, which in Brazil, is the major producer of food, suffers differently than the population that inhabits the urban environment (BORTOLOTTO et al., 2018). The most prevalent differences concern demographic and socioeconomic aspects, such as lower education and average monthly income. Different pressures are also highlighted, such as air quality, noise pollution and lifestyle (MOREIRA et al., 2015).

In agriculture, we have the highest incidence of small rural properties organized according to family farming. It is very common for this producer to work alone or with his entire family, and yet, among workers, there may be an internal division of labor. The more agribusiness predominates, the more compromising the living and working conditions are and thus causing the wear and tear represented by the extension of the working day, intensification of its pace, payment for production, real decrease in the value of wages, noncompliance with labor rights and deterioration in their quality of life (PESSOA et al., 2014).

According to Guimarães (2000), of the current Brazilian population, the people who have less access to basic needs and who most have precarious conditions of work and income, are those who live and survive in the countryside. Riquinho (2010), when studying the subjective dimensions and social identity of rural workers, points out that, in the view of rural workers, the disease goes beyond numerous physical limits and health conditions, always relating to the work to which they are inserted.

Aside from the physical and psychological ardor, there is still another factor that has been growing without the public notoriety of its maleficence. This is the case of crop protections and their exacerbated use, there have been many discussions about cases of intoxication by farmers due to their exposure to crop protections, especially at the time of application, as shown by the study by Wahlbrinck et al. (2017). Ribas et al. (2009), lists two types of effects directly linked to this use, they are: a) acute effects, or those that result from exposure to concentrations of one or more toxic agents, capable of causing apparent effective damage within a 24-hour period; b) chronic effects, or those that result from continued exposure to relatively low doses of one or more products.

Crop protection, popularly known as pesticides, have a great dispersion capacity and can be found in soil, water, air, animals and vegetables, as well as in humans. Despite not having a minimum structure and not even previous knowledge to handle them, many families work with these chemicals, consequently, their intoxication can decrease immune defenses, cause anemia, sexual impotence, headache, insomnia, blood pressure changes, dysthymias and behavioral disorders. These manifestations are common among farmers, sometimes determining the medical prohibition of working in the fields and the orientation for another type of professional activity (PEREIRA et al., 2015; LEVIGARD et al., 2004).

However, it is necessary to make an alert, even if some of the active ingredients of crop protections are classified as low toxic or of low disease capacity, it cannot be forgotten that the use in an indefinite period 
of time makes them chronic if present in the form of diseases such as cancers, congenital malformation, endocrine, neurological and mental disorders (CARNEIRO et al., 2012).

Therefore, quality of life (QOL), according to numerous studies, arises from the need to know the environmental, social, psychological and physical aspects of human life, as well as the relationship between these four domains. According to the WHOQOL Group (WHOQOL GROUP, 1995), they also defined QoL as the individual's perception according to their position in life, in the context of culture, and the value systems in which they live, and, in relation to their goals, expectations, standards and concerns .

Regarding the study site, the Taquari Valley, is located in Rio Grande do Sul and is composed of 36 municipalities that stand out in the agricultural sector. Since the use of crop protections is a common practice and studies on the characteristics of occupational use or on pesticide poisoning are scarce, this study presents data on rural properties with dairy production in the Taquari Valley in relation to the use of crop protections, types of crop protections, quality of life and microbiological quality of water, aiming to associate these variables. Also, to evaluate the analyzes (physical-chemical) and the quality of life in its four scores: physical, social, environmental and psychological and, finally, it aims to highlight future health problems, in addition to water contamination.

\section{MATERIALS AND METHODS}

This study was approved by the Ethics Committee of the University of Vale do Taquari (Univates) under the number CAAE 29640520.6.0000.5310.

\section{Study area}

The Taquari Valley is located in the central region of the state of Rio Grande do Sul - Brazil, being composed of 36 municipalities that stand out in the agricultural sector (FIGURE 1). It has a population of approximately 356 thousand inhabitants, which is equivalent to $2.97 \%$ of the population of Rio Grande do Sul, the vast majority being of German, Italian or Azorean origin. The study was carried out in rural properties with dairy production, in the municipalities that make up the region.

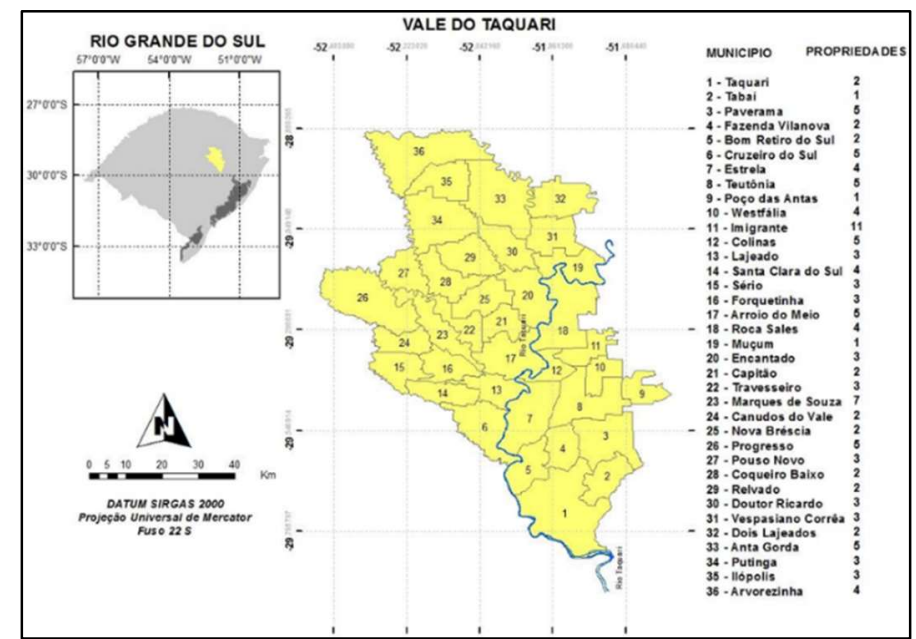

Figure 1: Taquari Valley map with the indication of the number of properties evaluated in the present study. Source: Scheifler et al. (2018). 
The region is situated in a large bacia of milk, chicken, pork and other products. This production is linked mostly, if not entirely, to family farming, predominant in the region. Therefore, according to the data mentioned above, it is up to this study to verify the quality of life and its relationship with the use of crop protections as a way of comparing what is used in the properties, and at the same time exploring what are the main problems that affect the lifestyle of that population.

\section{Methods}

The agriculture and EMATER secretariats of the 36 municipalities in the region were visited and consulted to present the proposal and define the properties participating in the research. The number of participating farms per municipality was defined taking into account the total milk production per municipality. After defining the properties, a schedule of on-site visits to the selected properties was established to survey the vertices of rural properties with the aid of GPS, the delimitation of natural elements and the demarcation of the types of land uses and coverings present on the property.

During this visit, producers were interviewed about how to dispose of waste, quality of water available for animal drinking and human consumption, use and coverage of APP and Legal Reserve, declivity of properties, aspects related to erosion, fires and form of land use. The script for interviews and questions to be observed in the field was adapted from Rempel et al. (2012) and Verona (2008). As for crop protections, questions were added according to Rempel et al. (2012), which are: a) about use: no use, controlled application, application throughout the property except around wells, streams and improvements, application throughout the property without control, application without control and close to water courses; b) the types of crop protections; and c) storage of packages: in a special covered deposit, separated from any medication, food, animal and safe from moisture, in a covered deposit, anywhere on the property and disposed of without care.

To identify the domains that determine your Quality of Life, the Whoqol-bref assessment instrument was applied. This instrument is a questionnaire that investigates the individual's perception of his Quality of Life. The instrument comprises 26 questions, through which four domains are investigated: Physical, Psychological, Environmental and Social Relations. The Whoqol-bref questions were formulated for a scale Lickert type, with a scale of intensity (nothing-extremely), capacity (nothing-completely), frequency (neveralways) and evaluation (very dissatisfied-very satisfied; very bad -very good) (FLECK, 2012).

The information obtained in the application of the questionnaires regarding crop protections was tabulated for a more efficient analysis. As for the answers to the Whoqol-bref questionnaire, these were tabulated and the Quality of Life indices were calculated with the aid of the Excel ${ }^{\circledR}$ spreadsheet, from a database built based on the calculations established for the evaluation of the present domains in the questionnaire. 


\section{RESULTS}

\section{Crop protection in rural properties with dairy production in Taquari Valley region}

Eighty six rural producers were interviewed. Regarding the use of crop protections on the property, 79 producers make controlled application, 11 of which do not control the application in the vicinity of wells, streams and improvements. Few, three producers, use crop protections without control and close to water courses. Of the total, only four producers do not use crop protections on the property. The majority, 65 producers, store the packaging of crop protection products in a covered deposit and 12 producers have a special deposit. Although four producers have stated that they do not use crop protection products, one replied that their storage of crop protection packaging is dispersed in different parts of the property. In addition to this, five other producers store their crop protection products dispersed in different parts of the property. Only one producer groups the packages anywhere on the property.

Of the 82 producers using crop protection products, the majority, $39 \%$, of the producers use two different crop protection products on their properties, followed by $35 \%$ of the producers using only one crop protection product (FIGURE 2). The most widely used crop protections are Roundup, Glifosato, Primóleo and Calisto, respectively.

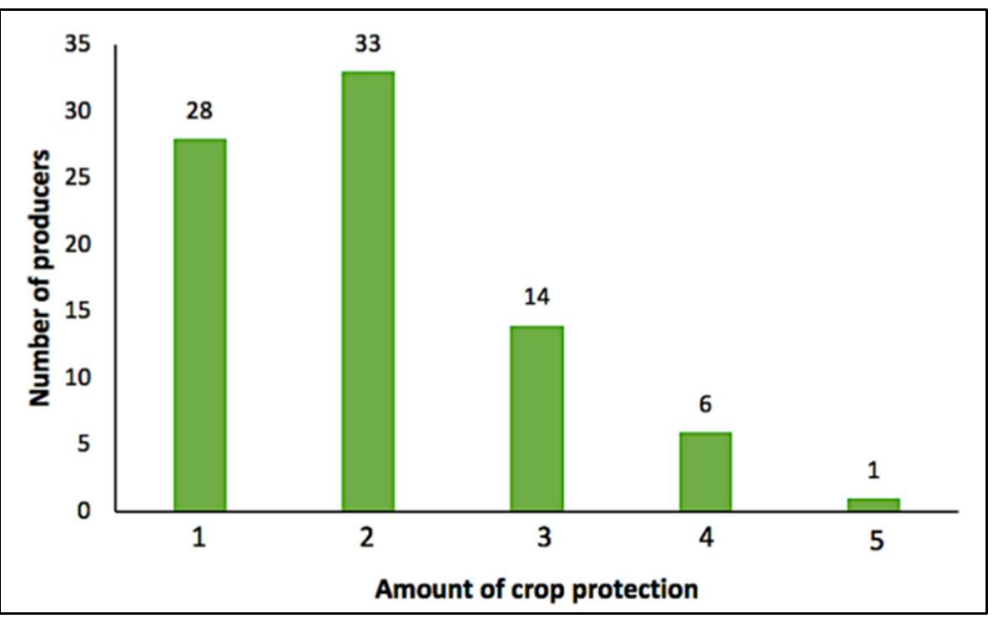

Figure 2: Number of crop protections used in rural properties with dairy production in Taquari Valley, RS.

\section{Quality of Life of dairy farmers in Taquari Valley region}

Figure 3 shows the mean and standard deviation of health perception, according to the classification of each QOL domain. There is no statistically significant difference in quality of life in the different scores assessed. As mentioned in the methodology, the questionnaire also allows the assessment of QOL in four domains and, when analyzing the questions in their respective areas, it was found that the 'social' domain obtained the best overall average, being $86.0(S D=13.7)$. The second with the highest average was 'physical' with $76.1(S D=13.3)$, followed by 'environmental' $77.2(S D=10.6)$. The domain that proved to be the most deficient was the psychological domain with an average of $72.2(\mathrm{SD}=10.6)$ (FIGURE 3). 


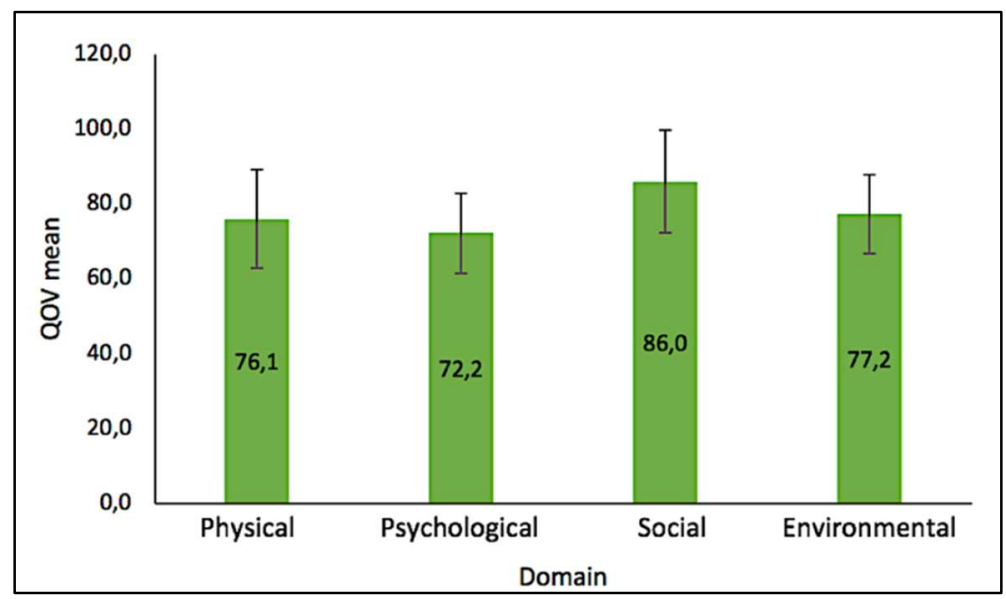

Figure 3: Average and standard deviation of quality of life scores of farmers with dairy production in Taquari Valley region participating in the survey.

Physical-chemical analysis of water from sources of supply destined for human consumption in rural properties with dairy production in Taquari Valley region

The results of the physical-chemical parameters of the 86 water samples collected and analyzed in rural properties destined for human consumption in the region of Taquari Valley and respective maximum allowed values (VMP) established by the consulted legislation are expressed in Table I.

Table 1: Average and standard deviation of water quality parameters for human consumption in Taquari Valley region, RS.

\begin{tabular}{|c|c|c|c|c|}
\hline & $\begin{array}{l}\text { V.M.P } \\
\text { Ordinance } \\
\text { M.S } \\
2914 / 2011\end{array}$ & $\begin{array}{l}\text { V.M.P Resolution } \\
\text { CONAMA } \\
357 / 2005 \text { (Class } \\
\text { special and 1) }\end{array}$ & $\begin{array}{l}\text { V.M.P } \\
\text { Resolution } \\
\text { CONAMA } \\
\text { 396/2008 } \\
\text { (Class 1) }\end{array}$ & $\begin{array}{l}\text { Average (SD) of water intended for } \\
\text { human consumption }\end{array}$ \\
\hline pH & 6,0 a 9,5 & 6,0 a 9,0 & Undefined & $7,40(0,91)$ \\
\hline Turbidity (NTU) & 5,0 & Up to 40 & Undefined & $2,45(4,79)$ \\
\hline $\begin{array}{l}\text { Dissolved Oxygen (mg } \\
\text { L-1) }\end{array}$ & Undefined & Not less than 6 & Undefined & $6,52(1,98)$ \\
\hline $\begin{array}{l}\text { Electrical conductivity } \\
\text { (uS } / \mathrm{cm} \text { ) }\end{array}$ & Undefined & Undefined & Undefined & $346,30(318,97)$ \\
\hline Color (mg L-1 Pt-Co) & 15 & $\begin{array}{l}\text { Natural color level of the } \\
\text { water body }\end{array}$ & Undefined & $9,48(13,41)$ \\
\hline $\begin{array}{l}\text { Total dissolved solids } \\
\text { (mg L-1) }\end{array}$ & 1000 & 500 & 500 & $243,44(156,66)$ \\
\hline
\end{tabular}

Based on a single collection of water in the 86 samples, it was possible to infer whether the physicalchemical characteristics were in accordance with the maximum allowed value (VMP) by the consulted legislation (Ordinance of the Ministry of Health No. 2914 of 2011, CONAMA Resolution no. 357 of 2005 and CONAMA Resolution No. 396 of 2008) (BRASIL, 2005; BRASIL, 2008; BRASIL, 2011).

Microbiological analysis of water from sources of supply for human consumption in rural properties with dairy production in Taquari Valley region

Table II presents the averages of the water quality variables for human consumption in the Taquari Valley. These presented quantities of total coliforms, from 11.45 UFC $100 \mathrm{~mL}-1$, and these values do not comply with the legislation, since this stipulates that drinking water should be absent from this type of organisms. In relation to the thermotolerant coliforms, they presented amounts of $4.23 \mathrm{CFU} 100 \mathrm{~mL}-1$, being, 
in the same way, in non-conformity, since in water for human consumption, the presence of coliforms makes the water unsuitable.

Table 2: Means (standard deviation) of total (UFC $100 \mathrm{~mL}-1$ ) and thermotolerant (UFC $100 \mathrm{~mL}-1$ ) coliforms of water intended for human consumption of the milk producing properties analyzed in Taquari Valley region, RS, Brazil.

\begin{tabular}{llllll}
\hline & V.M.P & $\begin{array}{l}\text { V.M.P } \\
*\end{array}$ & $\begin{array}{l}\text { V.M.P } \\
* * *\end{array}$ & $\begin{array}{l}\text { V.M.P } \\
* * * *\end{array}$ & Average human consumption \\
\hline Total coliforms (UFC/100mL) & 0 & Undefined & Undefined & Undefined & $11,45(35,62)$ \\
Thermotolerant coliforms (UFC/100mL) & 0 & 0 & 200 & 1000 & $4,23(13,76)$ \\
\hline
\end{tabular}

Caption: V.M.P. Maximum Allowable Values. * MS Ordinance No. 2914/2011. ** CONAMA Resolution No. 396/2008 (Class I). ${ }^{* * *}$ CONAMA Resolution No. 396/2008 (Class III). ${ }^{* * * *}$ CONAMA Resolution No. 357/2005 (Class III).

\section{DISCUSSION}

Of the total number of producers involved in the study, the vast majority make use of crop protections on their rural properties in a controlled manner. It is worth mentioning that approximately ten producers use it in the vicinity of wells, streams and improvements. According to results found in the municipalities of Taquari Valley-RS, the use of own wells is the main source used in human supply (ECKHARDT et al., 2009; ZERWES et al., 2015; MACEDO et al., 2018), therefore, it is essential, both for the rural community and the region, to make constant diagnoses about the characteristics and degree of potability in these wells, streams and improvements. Mainly because they are areas with livestock.

In relation to producers who use crop protections, $39 \%$ and $35 \%$ use two and only one pesticide, respectively. In most of the properties that make use of pesticide producers, the packaging is stored in a covered deposit, with approximately ten producers having a special deposit. As a result, it is known that producers run certain health risks, as they are directly exposed to these chemicals and cannot relate their harm to health. This is notable when they refer to individual protection equipment, where most of them do not use it, or do it incorrectly, aggravating the situation. There are more factors that can further aggravate the case, one of which is the non-reading of the labels causing the lack of information regarding the correct use and ideal dosages.

The environment also ends up suffering from the aforementioned negligence. Several of these chemicals end up causing soil diseases and even negatively affecting the region's native fauna and flora. There is also the inappropriate disposal of packaging, which is worrying because leaks of the remaining product can occur and leak significantly to some watercourse, contaminating it.

These data corroborate the study by Wahlbrinck et al. (2017) when analyzing the perception of farmers in a city in the same region about the risks of exposure to crop protections. However, as far as the science regarding the harm is concerned, the researchers realized that in that municipality the producers are aware of the possible damage to health, which may demonstrate an information policy on the subject in the locality.

As for the QOL of the producers who participated in the present study, including all domains, it was found that the average is considered adequate when compared to other studies in the area. Almeida-Brasil et al. (2017), when studying Quality of life (QOL) and characteristics associated with the application of WHOQOL-BREF in the context of Primary Health Care, measured an average of $63.9 \pm 18.8$ for the Center- 
South region of Brazil. Thus, the producers studied would be within the level of the standard curve presented by the study.

The same authors mentioned above also studied the domains individually. When comparing the means, the psychological, physical and social domains similarly fit the standard deviation (SD) curves of the study, except for the environmental domain, which taking into account the SD ( \pm 16.2 ), the Taquari Valley properties still exceed the result by 8.42 points, demonstrating a better quality of the environment (ALMEIDA-BRASIL et al., 2017).

A study by Siqueira et al. (2013), carried out with 343 rural producers in Pernambuco, shows that the averages of the domains found in the locality were quite similar to the present study, demonstrating a certain similarity in the lifestyle and quality of life of rural producers in both states. Another study carried out in the state of Rondônia (MOURA et al., 2019), showed scores, in general, lower than the present study, and the domains "physical", "social" and "environmental" had an average lower than 60, and the one with the highest score, "psychological", presented the average score of approximately 62. In the present study, for the "psychological" domain the average score found was approximately 72 , being above that found by the study cited.

Regarding the domains evaluated in the Whoqol-bref, the producers had a better average of QOL in the "social" domain and a lower average in the "psychological" domain. According to another study, it was found that the physical domain was the one with the lowest score, and the low score may be related to the advanced age of the participants in this (BOMBARDELLI et al., 2017).

It was found that, in general, producers are satisfied with the environment in which they live, as it is located away from the urban area and with that, they have more contact with nature and remain more distant from noises that may become unpleasant as horns, among others, and for that reason, the "environmental" domain obtained the second highest score. In relation to the "social relations" domain, a good average was evidenced, with this domain being the one with the highest score in the present study. Corroborating the data, a study by Bombardelli et al. (2017), also carried out using the WHOQOL-BREF questionnaire, shows that elderly people living in rural areas had the highest scores in the domains "social relations" and also "environment", as they report, in rural areas, there are friendships longer lasting and a different lifestyle, in addition to greater contact with nature, providing a better quality of life.

The guarantee of safe and reliable water consumption is given through physical-chemical parameters (RICHTER et al., 2013). Through these parameters it is also possible to quantify how much a water body is being modified due to the direct and/or indirect addition of substances that, for its use, may require a more complex treatment for viability or even non-viable with varied damages, in scope and severity to living beings (SPERLING, 2005; BORTOLI et al., 2017a). Based on the collection of water for physical-chemical analysis of water from sources of supply intended for human consumption in this study, it was possible to infer that the physical-chemical characteristics are in accordance with the consulted legislation (BRASIL, 2005; BRASIL, 2008; BRASIL, 2011).

The hydrogen potential $(\mathrm{pH})$ represents the acidic or alkaline conditions of the liquid medium. 
Considering the sanitary conditions, only extremely acidic or basic waters can cause some type of irritation to the skin and eyes (SPERLING, 2005; NOGUEIRA et al., 2015). This parameter must be monitored by improving treatment processes, preserving pipes against corrosion and helping to control disinfection (SPERLING, 2005; BORTOLI et al., 2017b; FUNASA, 2006).

Untreated water generally has high turbidity and color parameters. Both parameters are associated with biological water contamination, because the greater the turbidity, the greater the increase in organic matter in the water and, consequently, the greater the chances of contamination by coliforms, in addition to the presence of the more turbid aspect in this (SPERLING, 2005; BORTOLI et al., 2017b; CORDEIRO, 2008).

Associated with conductivity, $\mathrm{pH}$, color, turbidity and thermotolerant coliforms, dissolved oxygen (DO) is an excellent parameter in water quality, representing the degree of water aeration. The excess of organic matter will result in low levels of dissolved oxygen because it compromises the presence of oxygen, which will be used in the degradation processes of this matter by bacteria and other microorganisms (BORTOLI et al., 2017a).

Indicating water changes, the electrical conductivity has its values increased as the number of total solids increases, so there is a correlation between the values of electrical conductivity and the values of total solids (BORTOLI et al., 2017a; APHA, 1995). Viruses, bacteria and parasites are some of the agents that use water as a vehicle of contamination, accounting for approximately $80 \%$ of the diseases that occur in developing countries (ALMEIDA, 2004; BORTOLI et al., 2018; AMARAL, 2011). Therefore, it is essential that water intended for human consumption has the characteristics of potability according to the legislation (BORTOLI et al., 2018).

As for the total and thermotolerant coliforms found in sources of supply destined for human consumption in the rural properties of this study, microbiological analyzes showed the presence of coliforms. According to the drinking water standards for human consumption regulated by the Ministry of Health Ordinance 2914/11, the absence of thermotolerant coliforms in $100 \mathrm{~mL}-1$ is required (BORTOLI et al., 2017a).

As it deals with rural properties with dairy production, the amount of coliforms present in the analyzed water samples may be related to the inadequate management of cattle manure, the infiltration of pits, which may be compromising the water table (BORTOLI et al., 2018).

\section{CONCLUSIONS}

From the present study it was possible to evaluate the current scenario of rural properties with dairy production in Taquari Valley in view of the use of crop protections, quality of life parameters and physicalchemical parameters of the water consumed. The results obtained point out that approximately $95 \%$ of the dairy properties of Taquari Valley analyzed in the study, use at least one type of pesticide on their property.

The physical-chemical analysis of the water was in accordance with the potability standards defined by Ordinance MS No. 2914/2011, except for the parameters related to coliforms, as they presented values higher than those recommended by the legislation. Regarding microbiological analysis, the values are in accordance with the maximum allowed values. 
The overall average QoL of rural producers was considered adequate for all domains, being above average. The 'environmental' and 'social relations' domains stood out, whose scores were the highest among the domains, indicating a good relationship between rural producers with friends and relatives and also with the environment in which they are inserted, referring to climate, noise and pollution.

Raising awareness of a better quality of life for rural producers, as well as ensuring environmental preservation due to the use of crop protections is a major challenge for society, and it is essential that rural producers seek partnerships with EMATER technicians, the Secretariat of Agriculture, the Secretariat of Environment and biologists, in order to minimize risks to human and animal health, and to the environment, ensuring quality of life for future generations.

\section{REFERENCES}

ALMEIDA, M. B.. Avaliação da qualidade microbiológica da água e qualidade de vida: estudo de caso de Carretéis e arredores - Itabaianinha/Sergipe. Dissertação (Mestrado) Universidade Federal de Sergipe, São Cristóvão, 2004.

ALMEIDA-BRASIL, C. C.; SILVEIRA, M. R.; SILVA, K. R.; LIMA, M. G.; FARIA, C. D. C. M.; CARDOSO, C. L.; MENZEL, H.-J. K.; CECCATO, M. G. B.. Qualidade de vida e características associadas: aplicação do WHOQOL-BREF no contexto da Atenção Primária à Saúde. Ciência \& Saúde Coletiva, v.22, n.5, p.1705-1716, 2017. DOI: https://doi.org/10.1590/1413$\underline{81232017225.20362015}$

AMARAL, M.. Análise microbiológica de caixas d'água de colégios estaduais de Foz do Iguaçu - Paraná. Monografia (Especialização em Ensino de Ciências) - Universidade Tecnológica Federal do Paraná, Medianeira, 2011.

APHA. American Public Health Association. Standard methods for the examination of water and wastewater. Washington: APHA, 1995.

BOMBARDELLI, C.; ROSA, L. H. T.; KELLER, P. S.; KLAHR, P. S.; ROSA, P. V.; PERES, A.. Quality of life of elderly people living in a municipality with rural characteristics in the countryside of Rio Grande do Sul, Brazil. Rev. Bras. Geriatr. Gerontol., v.20, n.1, p.85-90, 2017. DOI: https://doi.org/10.1590/198122562017020.160082

BORTOLI, J.; REMPEL, C.; MACIEL, M. J.; SALVI, L. C.. Qualidade físico-química da água em propriedades rurais com produção de leite no Vale do Taquari-RS. Caderno Prudentino de Geografia, v.1, n.39, p.81-102, 2017a.

BORTOLI, J.; TONETTO, J. F.; TOLDI, M.; ZERWES, C. M.; SECCHI, M. I.; CALDERAN, T. B.; OLIVEIRA, E. C.; SANTANA, E. R. R.. Qualidade da água de poços particulares do município de Encantado, Vale do Taquari-RS. Revista Caderno

Pedagógico, v.14, n.1, p.217-229, 2017b. DOI:

http://dx.doi.org/10.22410/issn.1983-

0882.v14i1a2017.1448

BORTOLI, J.; MACIEL. M. J.; SANTANA, E. R. R.; REMPEL, C.. Avaliação microbiológica da água em propriedades rurais produtoras de leite localizadas no Rio Grande do Sul, Brasil. Revista Brasileira de Higiene e Sanidade Animal, v.12, n.1, p.39-53, 2018.
BORTOLOTTO, C. C.; MOLA, C. L.; TOVO-RODRIGUES, L..

Quality of life in adults from a rural area in Southern Brazil: a population-based study. Revista de Saúde Pública, v.52, n.1, 4s, 2018.

BRASIL. Ministério da Saúde. Portaria n. 2914 de 12/12/2011. Dispõe sobre os procedimentos de controle e de vigilância da qualidade da água para consumo humano e seu padrão de potabilidade. Brasília: DOU, 2011.

BRASIL. Resolução CONAMA n. 357, de 17/03/2005.

Classificação de águas, doces, salobras e salinas do Território Nacional. Brasília: CONAMA, 2005.

BRASIL. Resolução CONAMA n. 396, de 3/04/2008. Dispõe sobre a classificação e diretrizes ambientais para o enquadramento das águas subterrâneas e dá outras providências. Brasília: DOU, 2008.

CARNEIRO, F. F.; PIGNATI, W.; RIGOTTO, R. M.; AUGUSTO, L. G. S.; RIZOLLO, A.; MULLER, N. M.; ALEXANDRE, V. P.; FRIEDRICH, K.; MELLO, M. S. C. D.. Dossiê ABRASCO, 2012: Um alerta sobre os impactos dos agrotóxicos na saúde. Rio de Janeiro: ABRASCO, 2012.

CORDEIRO, W. S.. Alternativa de tratamento de água para comunidades rurais. Rio de Janeiro: Centro Federal de Educação Tecnológica de Campos, 2008.

ECKHARDT, R. R.; DIEDRICH, V. L.; FERREIRA, E. R.; STROHSCHOEN, E.; DEMAMAN, L. C.. Mapeamento e avaliação da potabilidade da água subterrânea do município de Lajeado, RS, Brasil. Ambi-Agua, v.4, n.1, p.58-80, 2009.

FLECK, M. P. A.. Desenvolvimento da versão em português do instrumento de avaliação de qualidade de vida da OMS (WHOQOL-100). Revista Brasileira Psiquiatria, v.21, n.1, p.19-28, 2012

FUNASA. Manual de Saneamento. 3 ed. Brasília: Fundação Nacional de Saúde, 2006

GUIMARÃES, D. R.. Desenvolvimento local e o agronegócio catarinense. Agropecuária Catarinense, v.13, p.25-40, 2000

LEVIGARD, Y. E.; ROZEMBERG, B. A.. Interpretação dos 
profissionais de saúde acerca das queixas de "nervos" no meio rural: uma aproximação ao problema das intoxicações por agrotóxicos. Cad. Saúde Pública, v.20, n.6, p.1515-1524, 2004.

MACEDO, T. L.; REMPEL, C.; MACIEL, M. J.. Análise físicoquímica e microbiológica de água de poços artesianos em um município do Vale do Taquari-RS. Tecno-lógica, v.22, n.1, p.58-65, 2018.

MOREIRA, J. P. L.; OLIVEIRA, B. L. C. A.; MUZIC, D.; CUNHA C. L. F.; BRITO, A. S.; LUIZ, R. R.. A saúde dos trabalhadores da atividade rural no Brasil. Cad. Saúde Pública, v.31, n.8, p.1698-1708, 2015. DOI: https://doi.org/10.1590/0102$\underline{311 \times 00105114}$

MOURA, W. N.; REMPEL, C.; KOETZ, L. C. E.. Qualidade e estilo de vida de produtores de leite em propriedades rurais de um município do Cone Sul de Rondônia. Cadernos UniFOA, v.14, n.40, p.127-137, 2019.

NOGUEIRA, F. F.; COSTA, I. A.; PEREIRA, U.. Análise de parâmetros físico químicos da água e do uso e ocupação do solo na sub-bacia do Córrego da Água Branca no município de Nerópolis - Goiás. Monografia (Bacharelado) - Escola de Engenharia Civil e Ambiental, Goiânia, 2015.

PEREIRA, R. A.; ALCÂNTARA, C. R.. Perfil do produtor rural no município de São João do Cariri e seus reflexos no processo produtivo: entre o tradicional e o moderno. Ciência e Natura, v.37, n.3, p.350-365, 2015.

PESSOA, Y. S. R. Q.; ALCHIERI, J. C.. Qualidade de vida em agricultores orgânicos familiares no interior Paraibano. Psicologia: Ciência e Profissão, v.34, p.330-342, 2014.

REMPEL, C.; ECKHARDT, R. R.; JASPER, A.; SCHULTZ, G.; HILGERT, I. H.; BARDEN, J. E.. Proposta metodológica de avaliação da sustentabilidade ambiental de propriedades produtoras de leite. Tecno-Lógica, v.16, n.1, p.48-55, 2012.

RIBAS, P. P.; MATSUMURA, A. T. S.. A química dos agrotóxicos: impacto sobre a saúde e o ambiente. Rev.
Liberato, v.10, n.14, p.149-158, 2009.

RICHTER, C. A.; NETTO, J. M. D. E. A.. Tratamento de água: tecnologia atualizada. São Paulo: Edgard Blücher, 2013.

RIQUINHO, D. L.. Doença e incapacidade: dimensões subjetivas e identidade social do trabalhador rural. Saúde Sociedade, v.19, n.2, p.320-332, 2010.

SCHEIFLER, A.; REMPEL, C.. Reservas Legais de Propriedades Rurais com Produção de Leite no Vale do Taquari. Estudo \& Debate, v.25, n.2, p.244-261, 2018.

SIQUEIRA, D. F.; MOURA, R. M.; LAURENTINO, G. E. C.; ARAÚJO, A. J.; CRUZ, S. L.. Qualidade de vida de trabalhadores rurais e agrotóxicos: um estudo com o Whoqol-Bref. R. Bras. Ci. Saúde, v.7, n.2, p.139-148, 2013.

SPERLING, M.. Introdução à Qualidade das Águas e Tratamento de Esgotos. 3 ed. Belo Horizonte: Departamento de Engenharia Sanitária e Ambiental; 2005.

VERONA, L. A. F.. Avaliação de sustentabilidade em agroecossistemas de base familiar e em transição agroecológica na região sul do Rio Grande do Sul. Tese (Doutorado em Ciências: Produção Vegetal-Doutorado) Universidade Federal de Pelotas, Pelotas, 2008.

WAHLBRINCK, M. G.; BICA, J. B.; REMPEL, C.. Percepção dos agricultores do município de Imigrante (RS) sobre os riscos da exposição a agrotóxicos. RBCIAMB, v.44, p.72-84, 2017.

WHOQOL GROUP. The world Health Organization quality of life assessment (WHOQOL): position paper from the world health organization. Soc Sci Med., v.41, n.10, p.1403-1049, 1995.

ZERWES, C. M.; SECCHI, M. I.; CALDERAN, T. B.; BORTOLI, J.; TONETTO, J. F.; TOLDI, M. OLIVEIRA, E. C.; SANTANA, E. R. R.. Análise da qualidade da água de poços artesianos do município de Imigrante, Vale do Taquari/RS. Ciência e Natura, v.37, n.4, p.651-663, 2015.

A CBPC - Companhia Brasileira de Produção Científica (CNPJ: 11.221.422/0001-03) detém os direitos materiais desta publicação. Os direitos referem-se à publicação do trabalho em qualquer parte do mundo, incluindo os direitos às renovaç̃ões, expansões e disseminações da contribuiç̃o, bem como outros direitos subsidiários. Todos os trabalhos publicados eletronicamente poderão posteriormente ser publicados em coletâneas impressas sob coordenação da Sustenere Publishing, da Companhia Brasileira de Produção Científica e seus parceiros autorizados. Os (as) autores (as) preservam os direitos autorais, mas não têm permissão para a publicação da contribuição em outro meio, impresso ou digital, em português ou em tradução. 